Primljen / Received: 23.1.2019. Ispravljen / Corrected: 10.5.2018.

Prihvaćen / Accepted: 24.6.2018.

Dostupno online / Available online: 10.3.2020.

\title{
Mechanical behaviour of PVC-CFRP confined concrete column with RC beam joint subjected to axial load
}

Authors:

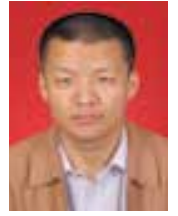

Prof. Feng Yu, PhD. CE

yufeng2007@126.com

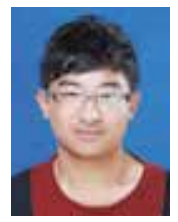

Zilong Li, MCE

708911028@q9.com

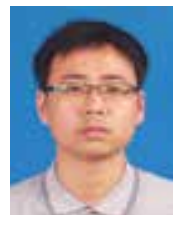

Assist.Prof. Fang Yuan, PhD. CE fyuan86@126.com

Autor za korespodenciju

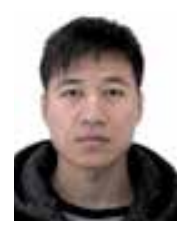

Defeng Zhu, MCE

760773504@q9.com

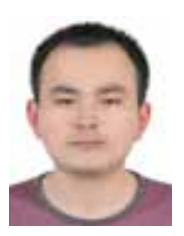

Zhengyi Kong, PhD. CE kzy2004@126.com

Anhui University of Technology, China Dept. of Civil Engineering and Architecture
Research Paper

Feng Yu, Zilong Li, Yuan Fang, Defeng Zhu, Zhengyi Kong

Mechanical behaviour of PVC-CFRP confined concrete column with RC beam joint subjected to axial load

An experimental investigation on failure mode, ultimate strength, strain variation, and load-displacement curves of PVC-CFRP confined concrete column with reinforced concrete (RC) beam joint (PCRBJ) subjected to axial load was conducted in this study. Samples of a PVC confined concrete column with RC beam joint (PRBJ) and nine PCRBJs were designed using the principle of weak column and strong joint. A numerical analysis approach for convenient prediction of the load-displacement curve of specimen was proposed. It was established that the estimated values are in good agreement with test data.

Key words:

PVC-FRP, reinforcement ratio, joint, ring beam, axial load, load-displacement curve

Prethodno priopćenje

Feng Yu, Zilong Li, Yuan Fang, Defeng Zhu, Zhengyi Kong

Mehanička svojstva spoja betonskog stupa ovijenog PVC-CFRP-om i AB grede pri osnom opterećenju

U radu je prikazano eksperimentalno istraživanje oblika loma, granične čvrstoće, deformacija i krivulja opterećenje-pomak spoja betonskog stupa obavijenog PVC-CFRP-om i AB grede (PCRBJ) za slučaj osnog opterećenja. Uzorci spoja betonskog stupa obavijenog PVC-om i AB grede (PRBJ) i devet uzoraka PCRBJ projektirani su prema načelu slabog stupa i čvrstog spoja. Predložen je pristup numeričke analize za prikladno predviđanje krivulje opterećenje - pomak. Utvrđeno je da se numerički predviđene vrijednosti dobro podudaraju s rezultatima ispitivanja.

Ključne riječi:

PVC-FRP, udio armature, spoj, prstenasta greda, osno opterećenje, krivulja opterećenje- pomak

Vorherige Mitteilung

Feng Yu, Zilong Li, Yuan Fang, Defeng Zhu, Zhengyi Kong

Mechanische Eigenschaften der Verbindung der mit PVC-CFK umwickelten Betonsäulen und der Stahlbetonträger bei Achsbelastung

Die Abhandlung präsentiert eine experimentelle Untersuchung der Bruchform, der Grenzfestigkeit, der Verformung und der Last-Verschiebungskurve der Verbindung einer mit PVC-CFK umwickelten Betonsäule und eines Stahlbetonträgers (PCRBJ) im Fall einer Achsbelastung. Die Proben der mit PVC umwickelten Betonsäule und des Stahlbetonträgers (PCRBJ) und neun Proben des PCRBJ wurden gemäß dem Grundsatz einer schwachen Säule und einer festen Verbindung konstruiert. Vorgeschlagen wurde ein nummerischer Analyseansatz, um eine Last-Verschiebungskurve angemessen vorherzusagen. Festgestellt wurde, dass die nummerisch vorhergesagten Werte gut mit den Testergebnissen übereinstimmten.

Schlüsselwörter:

PVC-FRP, Bewehrungsanteil, Verbindung, Ringträger, Achsbelastung, Last-Verschiebungskurve 


\section{Introduction}

Fibre reinforced polymer (FRP) has been widely utilized in engineering repairs due to its good durability, fatigue resistance, convenient structure, and corrosion resistance. Good reinforcing effect of FRP has already been achieved in the repair of members, such as walls, columns, beams, and plates [1-8]. The members strengthened with FRP show good bearing capacity, ductility and seismic resistance. Recently, it has been suggested to use FRP in some new structural elements, such as concrete-filled square steel tubes with FRP-confined concrete [9], FRP-reinforced concrete beams [10], and FRP confined concrete columns [11]. Mirmiran [11] proposed FRP tube concrete columns, and investigated their behaviour using experimental approach. Results demonstrated that FRP tube had a constraining effect on the core concrete, which significantly improved the ultimate strength and ductility of FRP tube concrete columns. However, the high cost hindered the application of FRP tubes in engineering. Hence, Saafi [12] proposed a PVC-CFRP Confined Concrete Column (PFCC) that used cheaper PVC tube wound by CFRP strips at the grooved section. Although the grooved PVC-FRP tube remarkably enhanced the ultimate strength and ductility of concrete, early failure of PVC tube may appear at the grooved portion due to stress concentration. To overcome this shortcoming, Yu $[13,14]$ proposed non-grooved PFCC. The ultimate strength and ductility of core concrete improved a lot compared to those of grooved PFCC. Jiang [15] and Ma [16] conducted a finite element analysis to study the axial performance of PFCCs. The results showed that the slenderness ratio and layers of CFRP strips exerted a great influence on the bearing capacity. A simplified formula for predicting the ultimate strength was proposed depending on the test data. Fakharifar [17] analysed the effect of the type and thickness of FRP tube, compressible foam, and the loading zone, on the behaviour of PFCC.

The experiment for the seismic resistance of PFCC was performed by Fakharifar [18], and high ultimate strength and good ductility of PFCC were demonstrated. Jiang [19] studied the influence of the axial force ratio, the layer and type of FRP on the circular section reinforced concrete composite column with FRP-PVC tube under cyclic loading. Good seismic performance and high energy consumption of PFCC were established. Yu $[20,21]$ examined the influences of various parameters such as
CFRP strip spacing, shear span ratio, and axial force ratio, on the seismic behaviour of PFCCs.

As described above, a number of publications focusing on PFCCs have been reported. However, the mechanical behaviour of PCRBJ is limited. The effect of $b, h, \rho, \rho_{\mathrm{sv}}$ and $s_{\mathrm{f}}^{\prime}$ on the performance of PCRBJ under axial load is investigated in this study.

\section{Experimental program}

\subsection{Specimen preparation}

Nine PCRBJ and one PRBJ were designed based on the principle of weak column and strong joint. The outer diameter (D), thickness $(\mathrm{t})$, and height $(\mathrm{H})$, of PVC tube were $200 \mathrm{~mm}, 7.8 \mathrm{~mm}$, and 500 $\mathrm{mm}$, respectively. Two layers of CFRP strips were wound around the PVC tube. The width and thickness of CFRP strips were $20 \mathrm{~mm}$ and $0.22 \mathrm{~mm}$, respectively, see Figure1. Three layers of CFRP strips were wrapped at the junction of joint and column to avoid premature failure at the interface between the column and the RC beam joint. The diameters of stirrups and longitudinal reinforcement were $6 \mathrm{~mm}$ and $10 \mathrm{~mm}$, respectively. The lengths of the encryption zone and non-encrypted zone were $150 \mathrm{~mm}$ and $350 \mathrm{~mm}$, respectively. The reinforcement ratios of stirrups in the encryption zone and non-encrypted zone were $1.18 \%$ and $0.59 \%$, respectively. The reinforcement ratio of longitudinal reinforcement was $2.0 \%$. Additional details are provided in Figure 2.

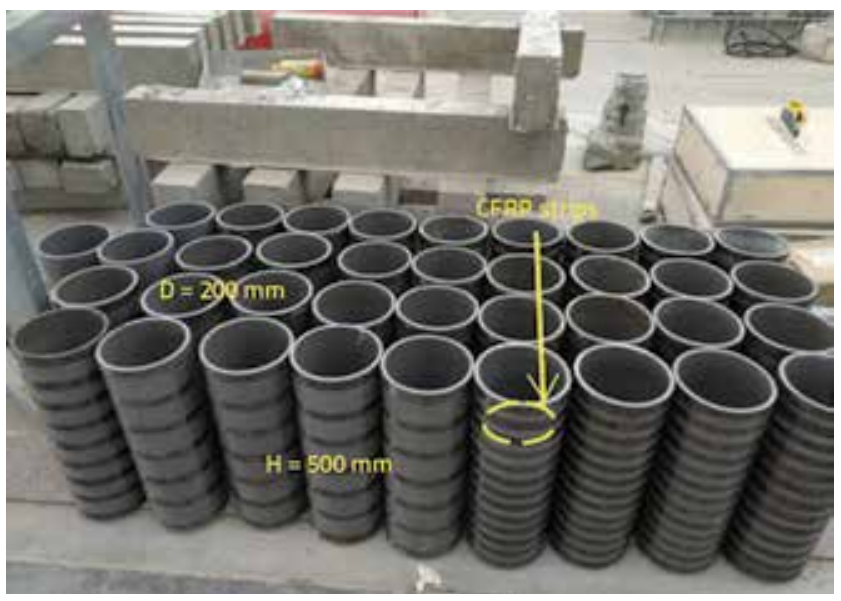

Figure 1. PVC-CFRP tubes

Table 1. Specimen parameters

\begin{tabular}{|c|c|c|c|c|c|c|c|c|c|c|}
\hline Specimen ID & A1 & A2 & A3 & A4 & A5 & A6 & A7 & A8 & A9 & A10 \\
\hline $\begin{array}{c}\mathrm{b} \times \mathrm{h} \\
(\mathrm{mm} \times \mathrm{mm})\end{array}$ & $75 \times 300$ & $100 \times 300$ & $125 \times 300$ & $75 \times 180$ & $75 \times 240$ & $75 \times 300$ & $75 \times 300$ & $75 \times 300$ & $75 \times 300$ & $75 \times 300$ \\
\hline$\rho[\%]$ & 1.45 & 1.45 & 1.45 & 1.45 & 1.45 & 1.85 & 2.25 & 1.45 & 1.45 & 1.45 \\
\hline$\rho_{\mathrm{sv}}[\%]$ & 0.85 & 0.85 & 0.85 & 0.85 & 0.85 & 0.85 & 0.85 & 0.85 & 1.70 & 0.85 \\
\hline $\mathrm{s}_{\mathrm{f}}^{\prime}[\mathrm{mm}]$ & 60 & 60 & 60 & 60 & 60 & 60 & 60 & 40 & 60 & - \\
\hline
\end{tabular}


a)

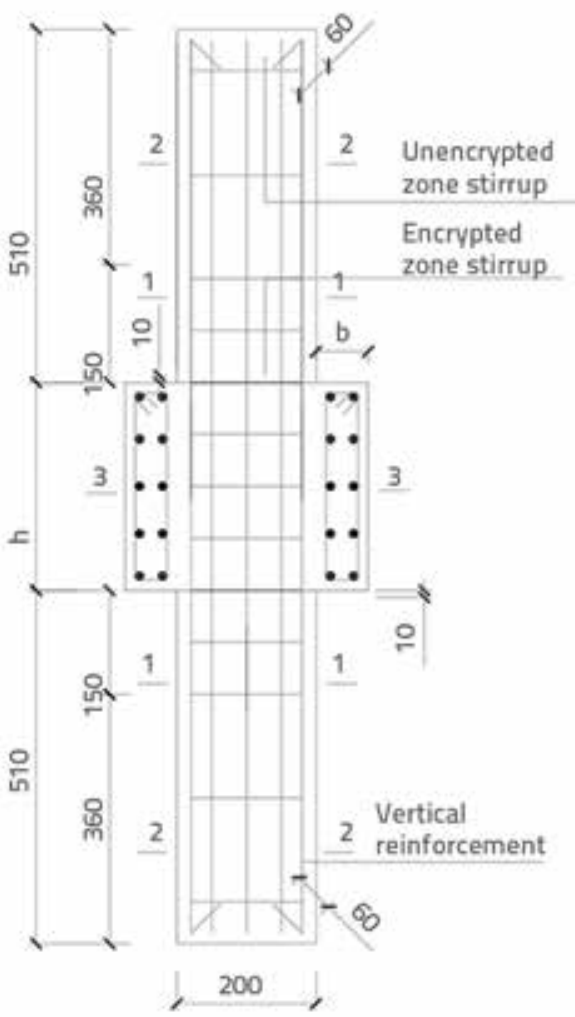

f)

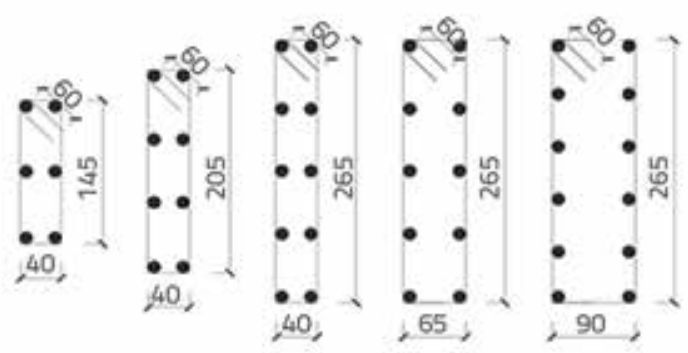

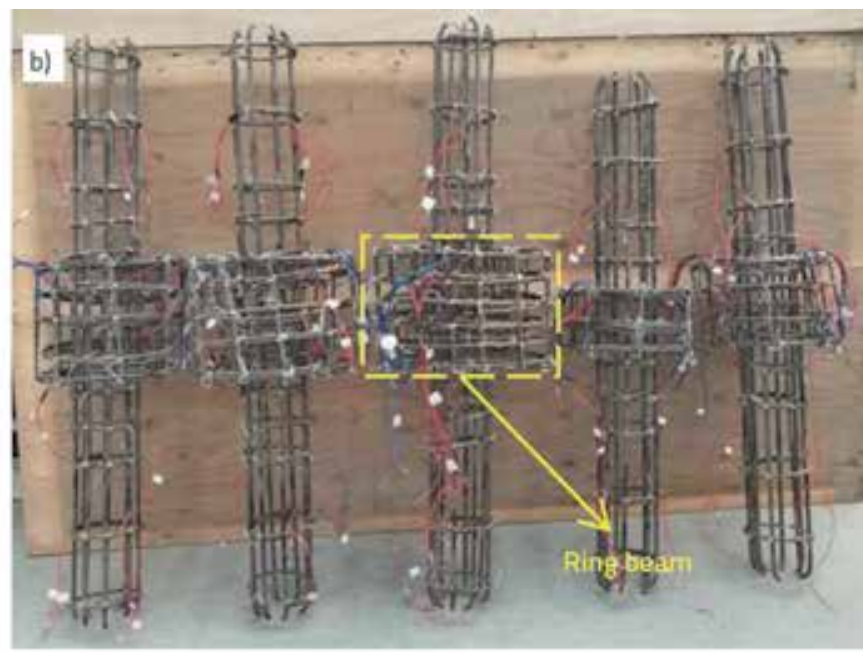

c)

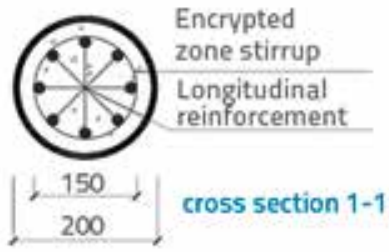

d)

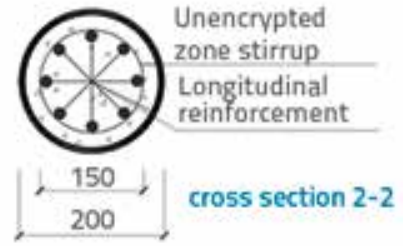

e)

Outer ring reinforcement of the ring beam
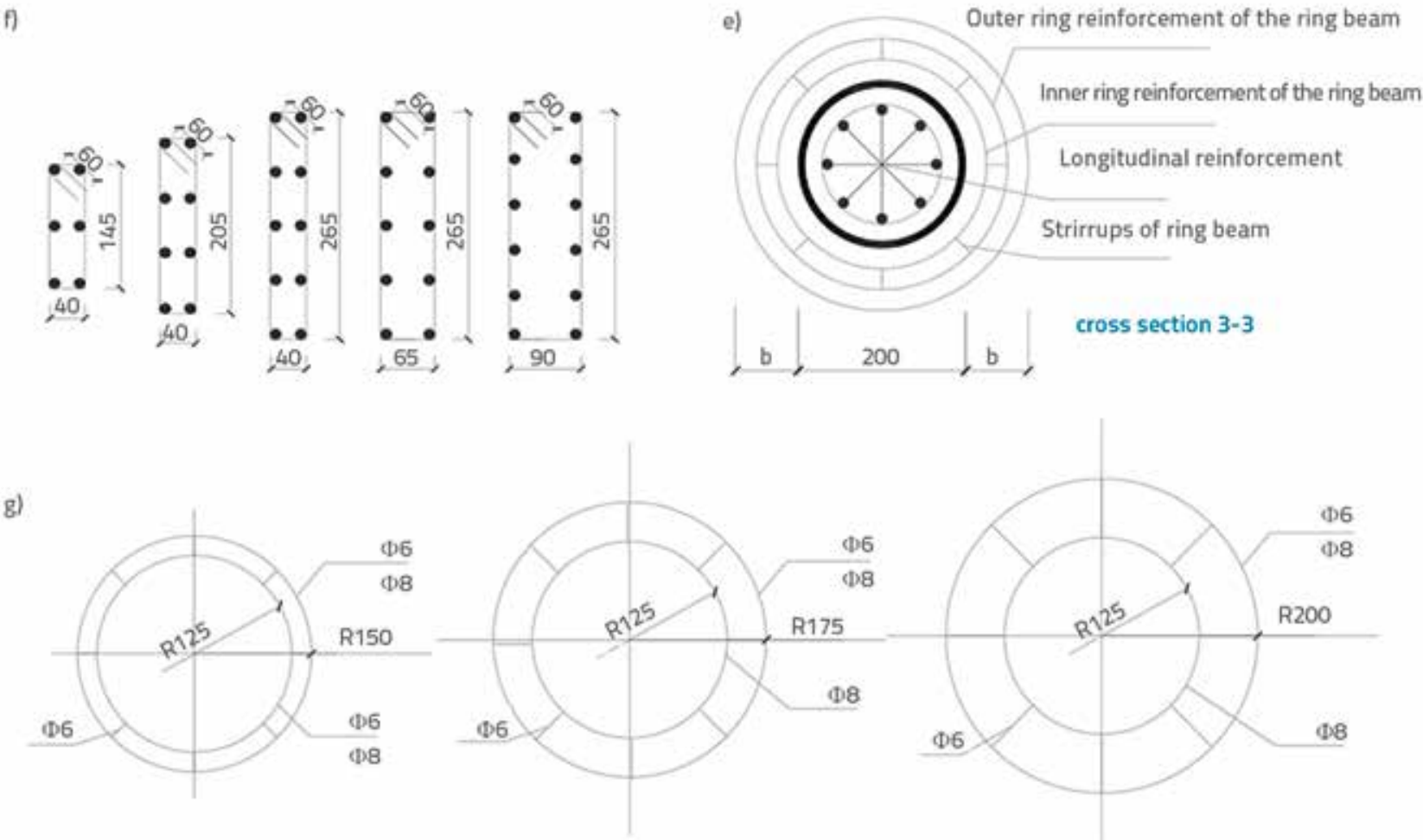

Figure 2. Detail of the reinforcement skeleton of specimens: a) Elevation view; b) Reinforcement skeleton; c) cross section 1-1; d) cross section 2-2; e) cross section 3-3; f) Stirrups in the ring beam; g) Reinforcement of ring beam 
Different spacing of winding CFRP strips considered were $40 \mathrm{~mm}$ and $60 \mathrm{~mm}$. Five different sections of ring beam, such as $75 \mathrm{~mm} \times 300 \mathrm{~mm}, 100 \mathrm{~mm} \times 300 \mathrm{~mm}, 125 \mathrm{~mm} \times 300 \mathrm{~mm}$, $75 \mathrm{~mm} \times 180 \mathrm{~mm}, 75 \mathrm{~mm} \times 240 \mathrm{~mm}$, were considered. The reinforcement ratios of ring beam were $1.45 \%, 1.85 \%$, and 2.25 $\%$, and the stirrups ratios of ring beam were $0.85 \%$, and $1.70 \%$ respectively, as shown in Table 1 . All members of each subassembly were cast at one time, as shown in Figure 3.
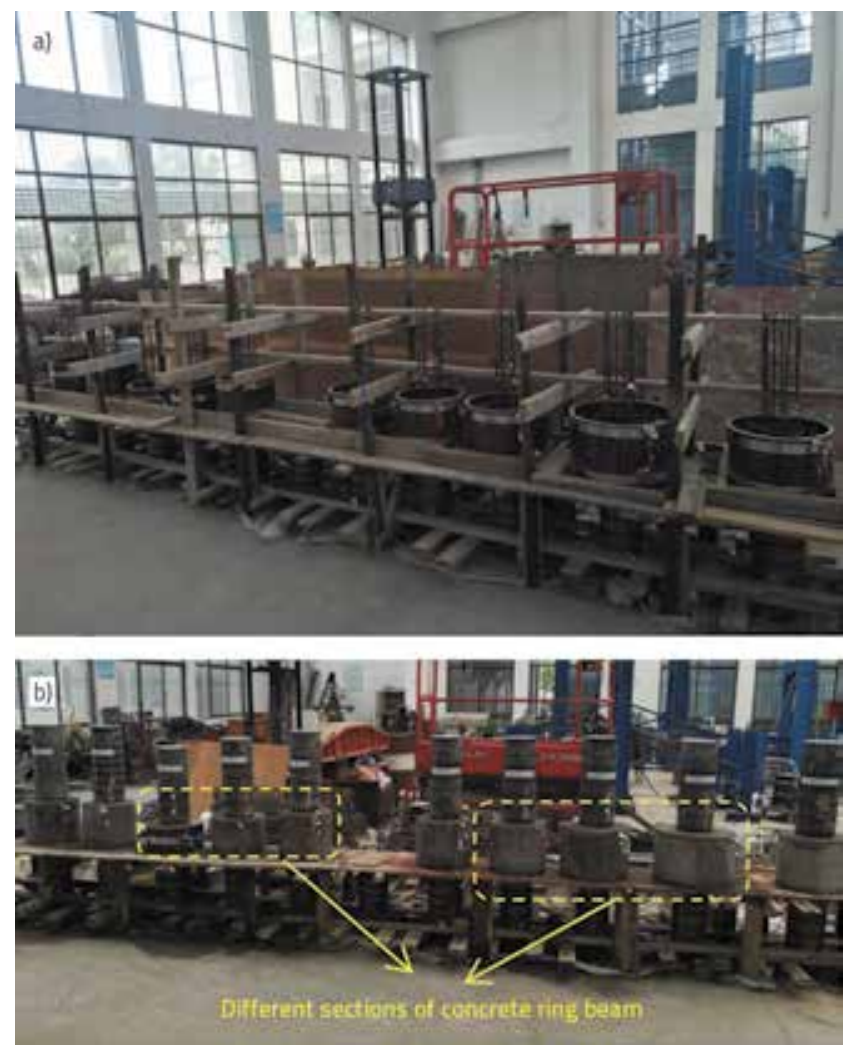

Figure 3. Specimen manufacturing process: a) Placement of reinforcement skeleton; b) PRBJ and PCRBJ

\subsection{Material properties}

HPB300 for reinforcement and stirrup and C35 concrete were utilized in this study. Mechanical properties of steel were determined according to Chinese code "Metallic materials - Tensile testing - Part 1: Method of test at room temperature" (GB/ T228.1 - 2010) [22], as shown in Table 2. The stress-strain curve of the PVC tube established from the axial compression experiment according to Chinese codes GB/T 8804.1 - 2003 [23] and GB/T 3354 - 2014 [24] is shown in Figure 4, while buckling of PVC tube is shown in Figure 5. Tensile strengths of PVC and CFRP were $62 \mathrm{MPa}$ and $3903 \mathrm{MPa}$, respectively. Concrete strength was estimated based on the test method specified in Chinese Code "Standard for test method of mechanical properties on ordinary concrete" (GB/T 50081- 2002) [25]. The compressive strength and Young's modulus of concrete were $24 \mathrm{MPa}$ and $2.4 \times 10^{4} \mathrm{MPa}$, respectively, as illustrated in Table 3.

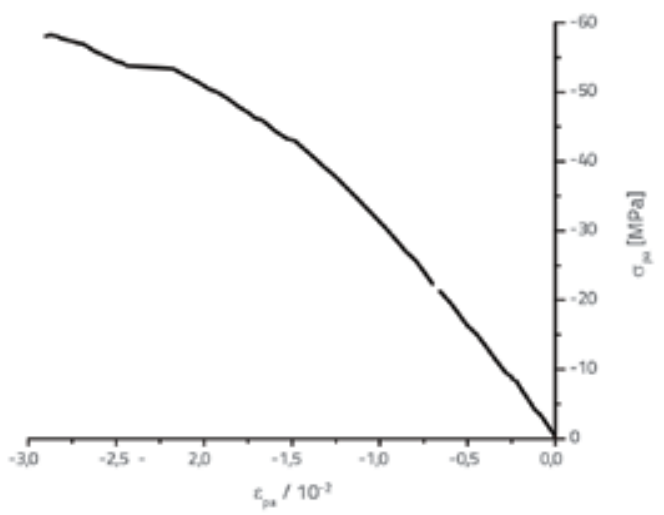

Figure 4. Stress-strain curve of PVC tube

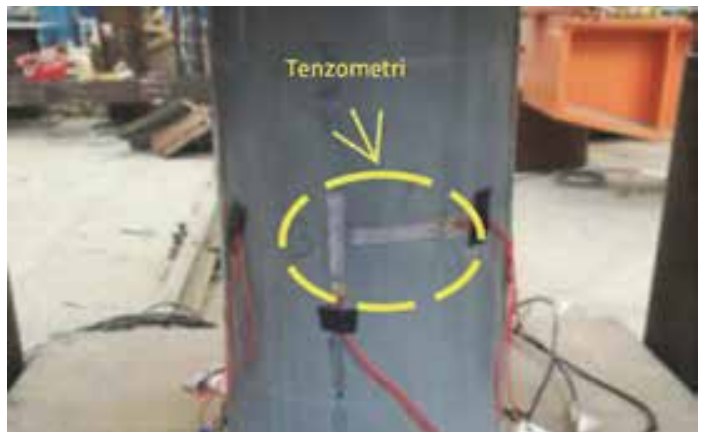

Figure 5. Failure mode of PVC tube

Table 2. Mechanical properties of reinforcement

\begin{tabular}{|c|c|c|}
\hline $\begin{array}{c}\text { Type of } \\
\text { reinforcement }\end{array}$ & $\begin{array}{c}\text { Yield strength } \\
{[\mathrm{MPa}]}\end{array}$ & $\begin{array}{c}\text { Tensile strength } \\
{[\mathrm{MPa}]}\end{array}$ \\
\hline$\Phi 6$ & 291 & 504 \\
\hline$\Phi 8$ & 277 & 430 \\
\hline$\Phi 10$ & 351 & 554 \\
\hline
\end{tabular}

Table 3. Mechanical properties of concrete

\begin{tabular}{|c|c|c|c|c|c|}
\hline $\begin{array}{c}\text { Specimen } \\
\text { number }\end{array}$ & $\begin{array}{c}\text { Strength } \\
\text { grade }\end{array}$ & $\begin{array}{c}\text { Cube } \\
\text { compressive } \\
\text { strength } \\
\text { [MPa] }\end{array}$ & $\begin{array}{c}\text { Compressive } \\
\text { strength } \\
{[\mathrm{MPa}]}\end{array}$ & $\begin{array}{c}\text { Elastic } \\
\text { modulus } \\
{\left[10^{4} \mathrm{MPa}\right]}\end{array}$ & $\begin{array}{l}\text { Average } \\
\text { compressive } \\
\text { strength } \\
\text { [MPa] }\end{array}$ \\
\hline 1 & \multirow{3}{*}{ C35 } & 36 & 24 & \multirow{3}{*}{2.4} & \multirow{3}{*}{24} \\
\hline 2 & & 36 & 24 & & \\
\hline 3 & & 35 & 23 & & \\
\hline
\end{tabular}

\subsection{Loading procedure and arrangement of instruments}

The test was performed using the electron-hydraulic servo compressive machine Type YAW-5000F. The test started by preloading with $5 \%$ of the estimated ultimate strength, which was to make sure that each instrument works properly. Force-controlled and displacement-controlled loading schemes were applied in the experiments. The experiments were initi- 
ated with the load-controlled program at the rate of $50 \mathrm{kN} /$ min. The load increment was 1/10 of the estimated ultimate strength of the specimen. Each load step kept constant for 2 minutes. After the axial compressive load attained approximately $90 \%$ of the estimated ultimate strength, the displacement-controlled method with $0.5 \mathrm{~mm} / \mathrm{min}$ was adopted. When the axial compressive load fell to $85 \%$ of the ultimate strength, the test was terminated. Four strain gauges were glued in the circumferential direction of the CFRP strip and 4 strain gauges were placed in the longitudinal direction of PVC tube for getting the circumferential and longitudinal strain of the concrete column of PVC-CFRP tube, as depicted in Figure 6.

a)
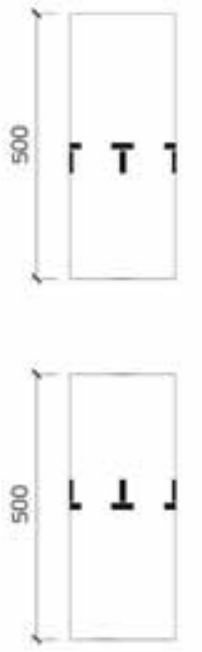
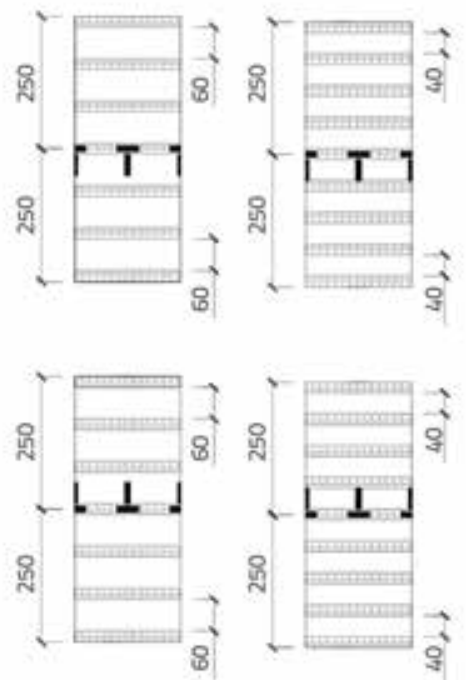

b)

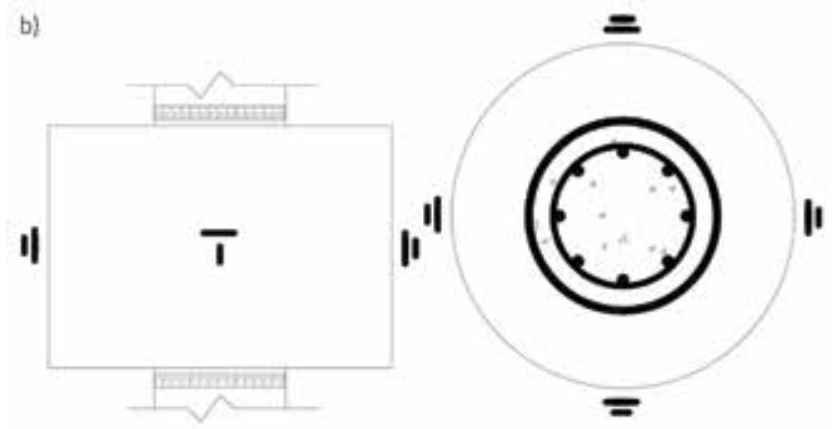

Figure 6. Arrangement of strain gauges in specimen: a) in the PVCCFRP tubes; b) in the joint zone

Additionally, eight strain gauges (arranged at $90^{\circ}$ ) were attached in the transverse direction and the longitudinal direction respectively at the centre of the joint zone for measuring the transverse and longitudinal strains of concrete in the joint zone. Two displacement transducers (i.e., W5 and W6) were arranged at the bottom of the specimen for measuring axial deformation, and another four displacement transducers (i.e., W1, W2, W3, and W4) were arranged at the upper and lower ends of the joint zone for measuring axial deformation of the joint zone. More details about the arrangement of instruments are presented in Figure 7.
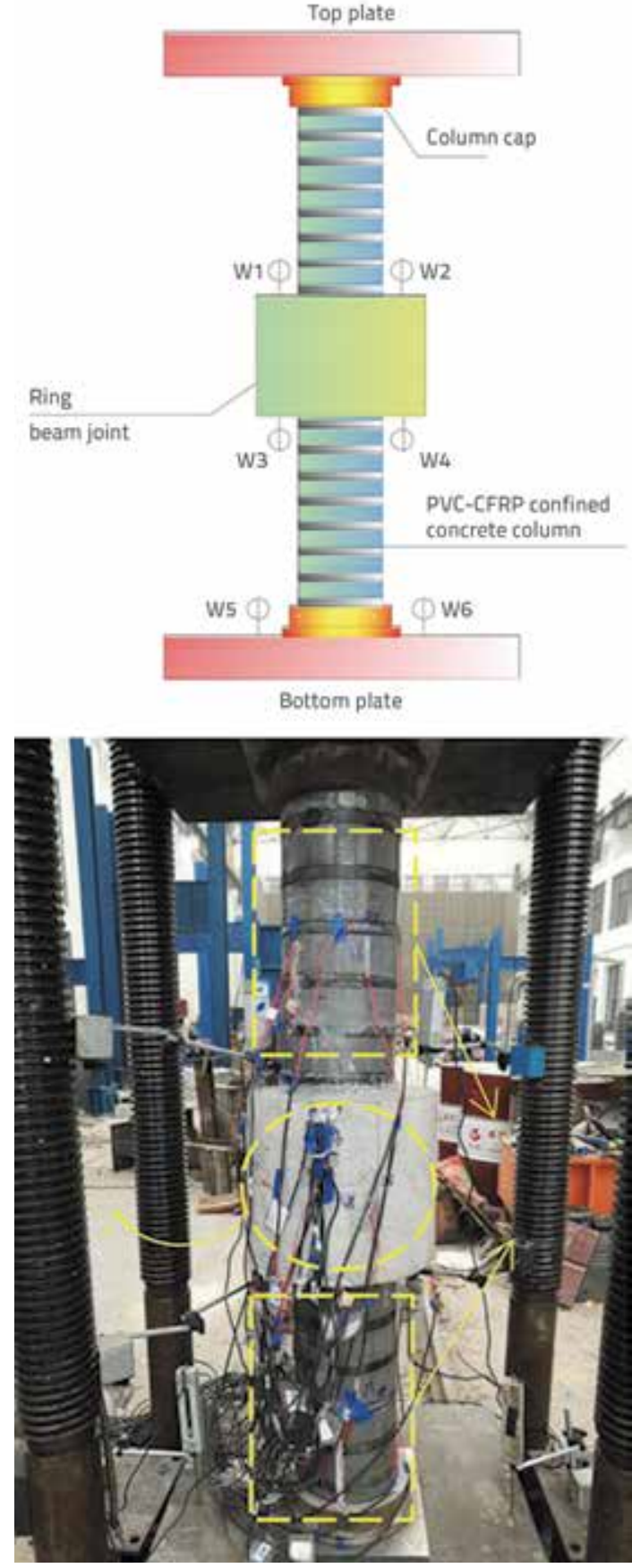

Figure 7. Test setup

\section{Experimental results and discussion}

\subsection{Failure modes}

\subsubsection{PRBJ specimen}

The PRBJ was damaged by the buckling of longitudinal reinforcement and PVC tube. As specimen was in elastic stage, the deformation of PRBJ was not remarkable. The concrete strain developed slowly, and PVC tube had little effect on the concrete. 


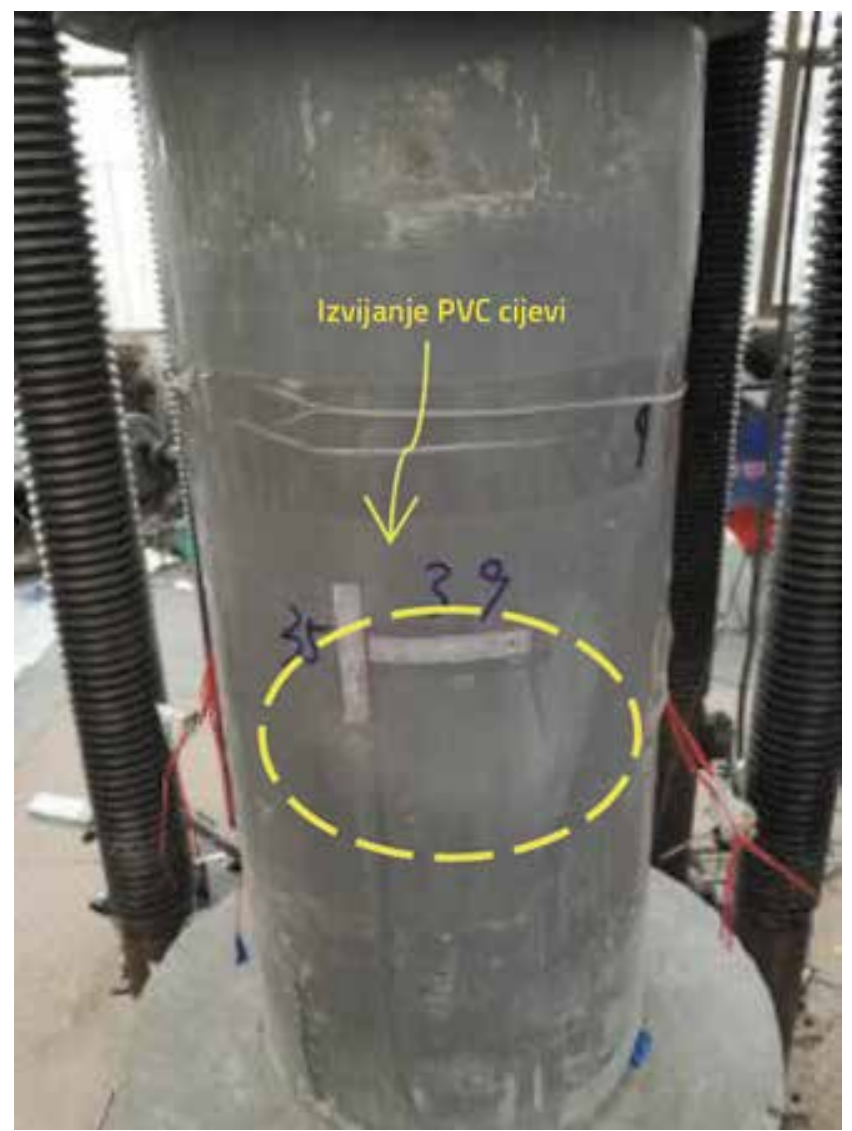

Slika 8. Oblik loma PRBJ uzorka

As load increased, PRBJ came into the crack developing stage. Subsequently, the volume of core concrete expanded rapidly and several small cracks occurred in the joint zone, which were then extended continuously. In addition, the development rate of PVC tube strain and the longitudinal reinforcement strain increased. When the load increased to approximately $80 \%$ of the ultimate strength of specimen, the longitudinal reinforcement yielded. Finally, as depicted in Figure 8, the PVC tube was buckled.

\subsubsection{PCRBJ specimen}

The PCRBJ was damaged with PVC tube cracking and CFRP strips fracture. The failure process of the PCRBJ was approximately composed of three stages. In the elastic stage, the deformation of PCRBJ, similar to the PRBJ, was not obvious. The strains of concrete, CFRP strips and longitudinal reinforcement developed slowly, and PVC tube had little effect on the concrete. As the load increased, the PCRBJ entered the crack developing stage. Several small vertical cracks occurred in the joint zone, The lateral deformation of concrete increased, and cracks in the concrete extended continuously. The development rate of CFRP strip strain and PVC tube strain increased rapidly, the confining effect of PVC-CFRP tube on column was obvious. When the load increased to approximately $90 \%$ of ul-
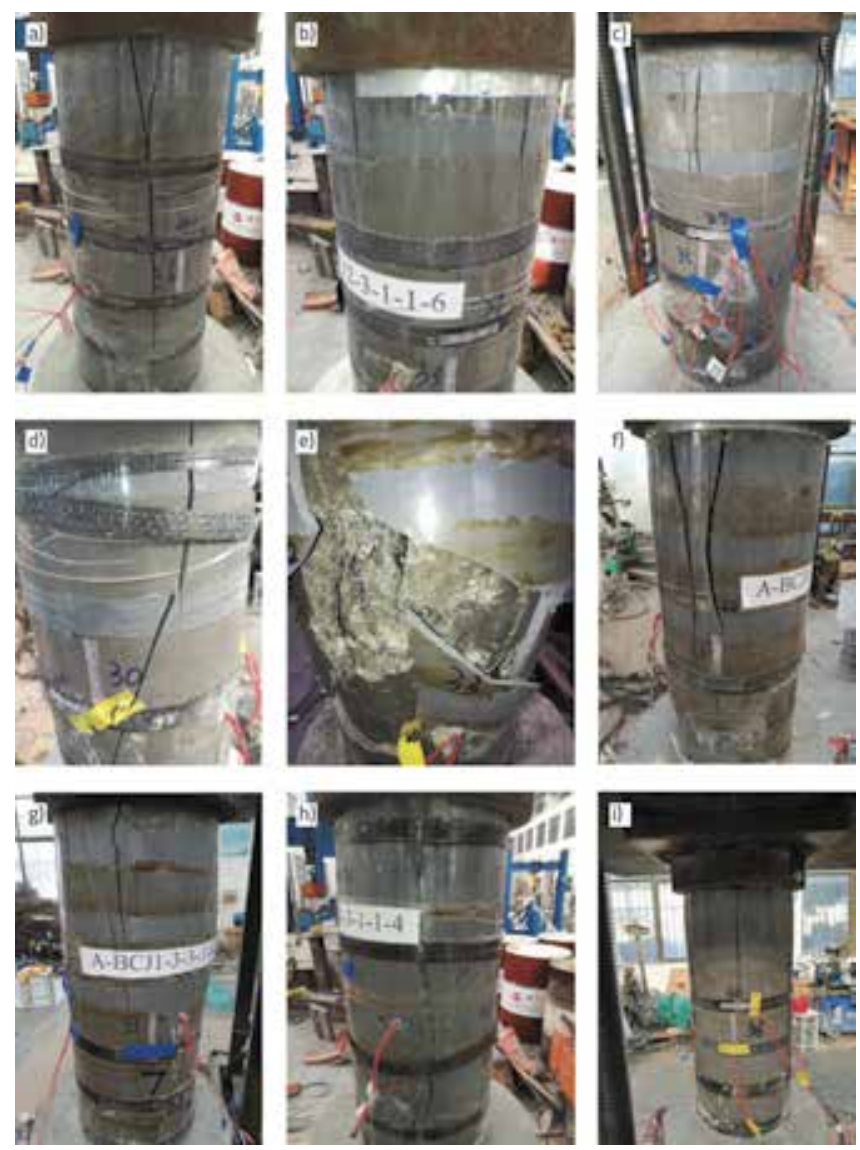

Figure 9. Failure mode of the PCRB,

timate strength, a loud sound demonstrating CFRP strips fracture could be heard. Eventually, as depicted in Figure 9, PVC tube cracked.

\subsection{Ultimate strength}

The influence of all studied parameters on ultimate strength is shown in Figure 10. Obviously, the influence of the $s_{f}^{\prime}$ on ultimate strength of specimen was significant, and the ultimate strength of specimen decreased as the $s_{\mathrm{f}}^{\prime}$ increased. This may come from that the increase in the $s_{\mathrm{f}}$ decreased the confinement effect of CFRP strips on specimen. For instance, the ultimate strength of the PCRBJ with the spacing of $40 \mathrm{~mm}$ was by $13.8 \%$ higher than that of the specimen with the spacing of $60 \mathrm{~mm}$. In contrast, the influence of the $b, h, \rho, \rho_{\mathrm{su}}$ on the ultimate strength of specimen was not obvious. Thus, the ultimate strength of the specimen increased by $4.1 \%$ when the $\rho$ increased from $1.45 \%$ to $1.85 \%$.

\subsection{Strain evolution}

\subsubsection{Axial strain of PVC tube}

The axial stress and strain curves $(\sigma-\varepsilon)$ are depicted in Figure 11. Obviously, with the increase of axial stress, axial strain 

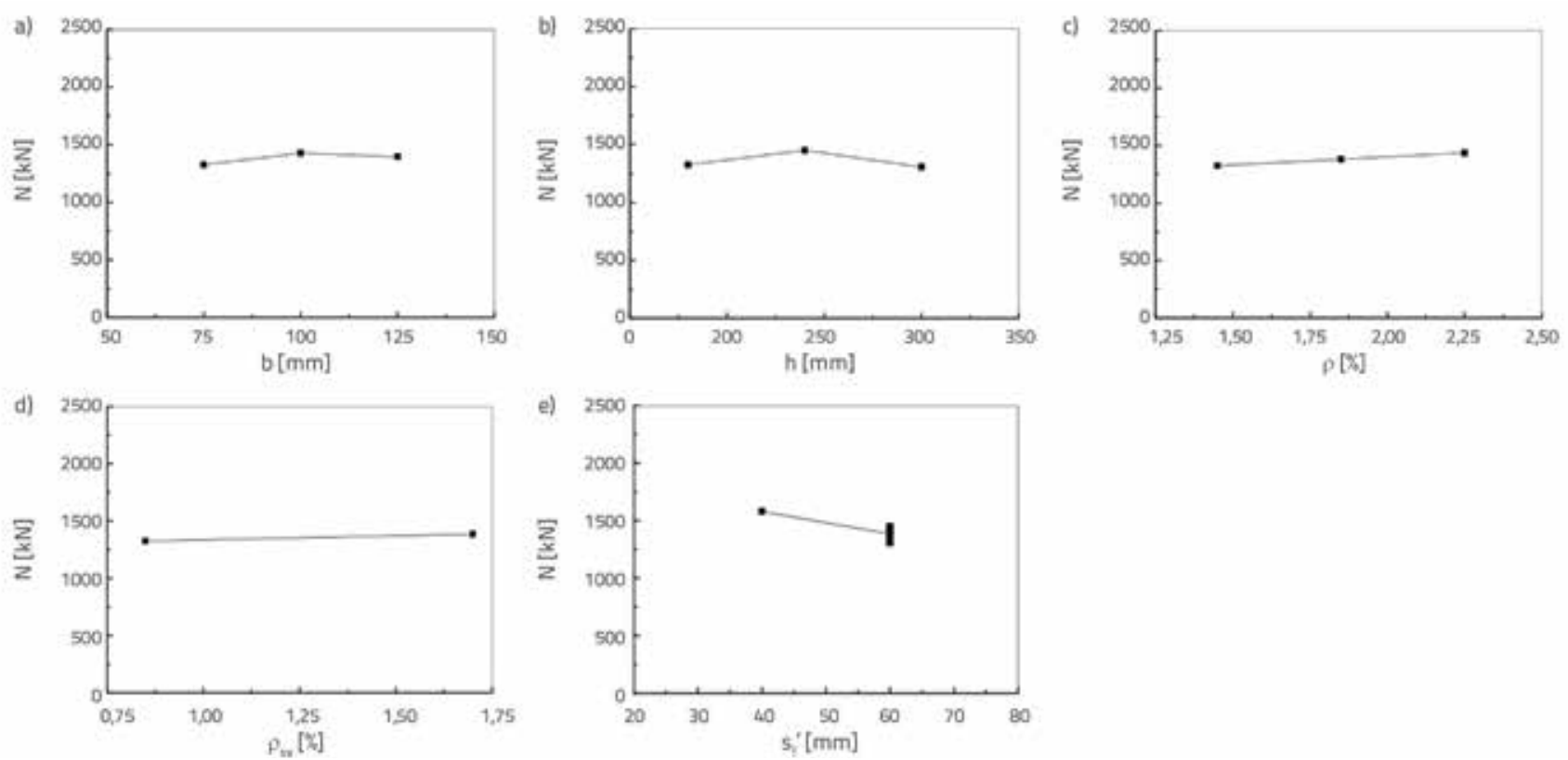

Figure 10. Effect of different parameters on ultimate strength of PCRBJ: a) Width; b) Height; c) Reinforcement ratio; d) Stirrup ratio; e) CFRP strip spacing
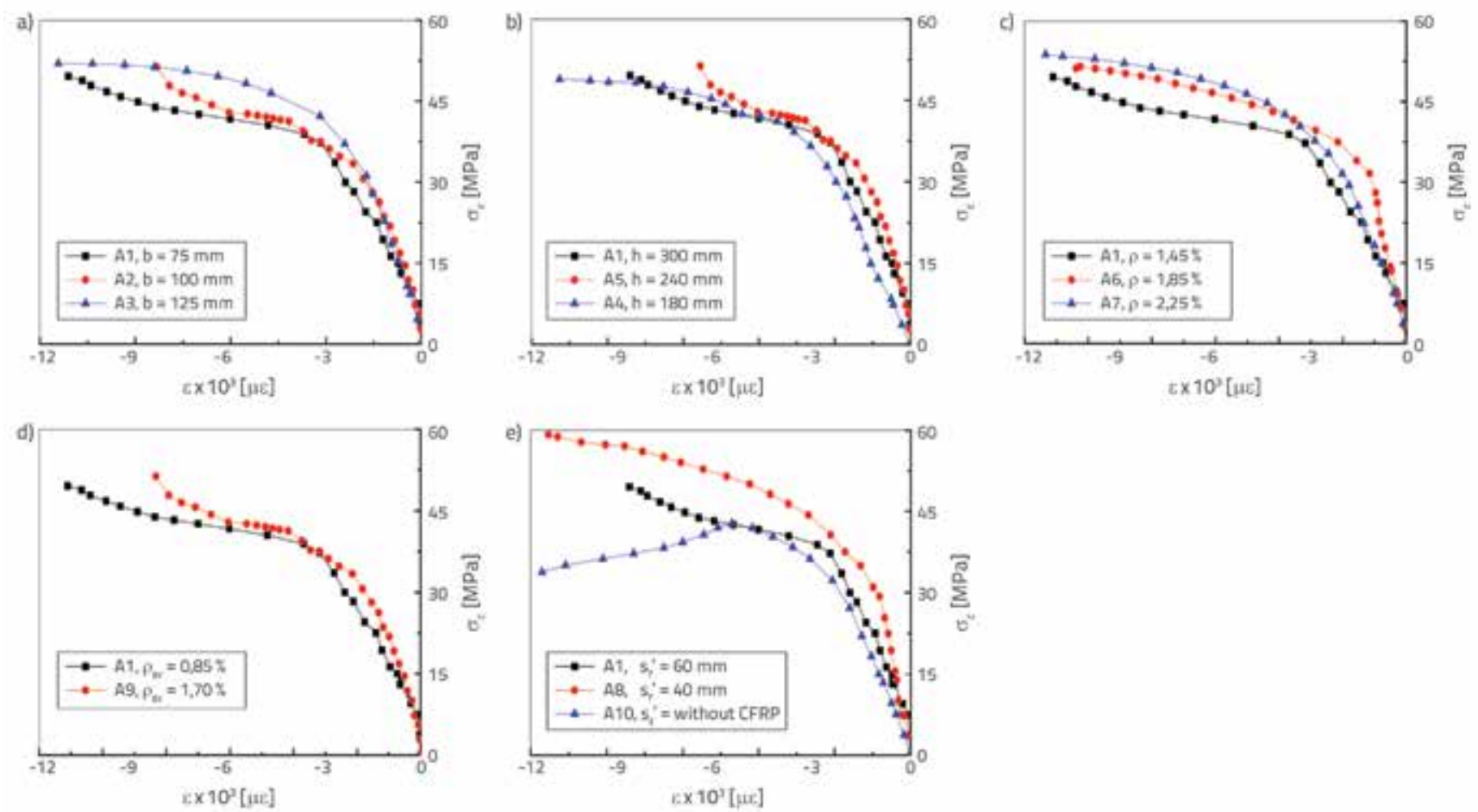

Figure 11. Effect of different parameters on axial strain of PVC tube: a) Width; b) Height; c) Reinforcement ratio; d) Stirrup ratio; e) CFRP strip spacing

of PVC tube linearly increased in the elastic stage. With the increase of load, the PCRBJ came to the stage of fracture development. The lateral deformation of concrete was obvious, and several small cracks appeared in the joint zone. The axial strain of PVC tube exhibited nonlinear behaviour and the increment of stress was not significant as the strain increased. Then, the PCRBJ entered the strengthening stage, and the stress of the PVC tube obviously increased as the strain increased. Finally, PCRBJ reached the ultimate strength and the PVC tube cracked.

In addition, various parameters had little effect on axial strain of the PVC tube in elastic stage. The ultimate axial 

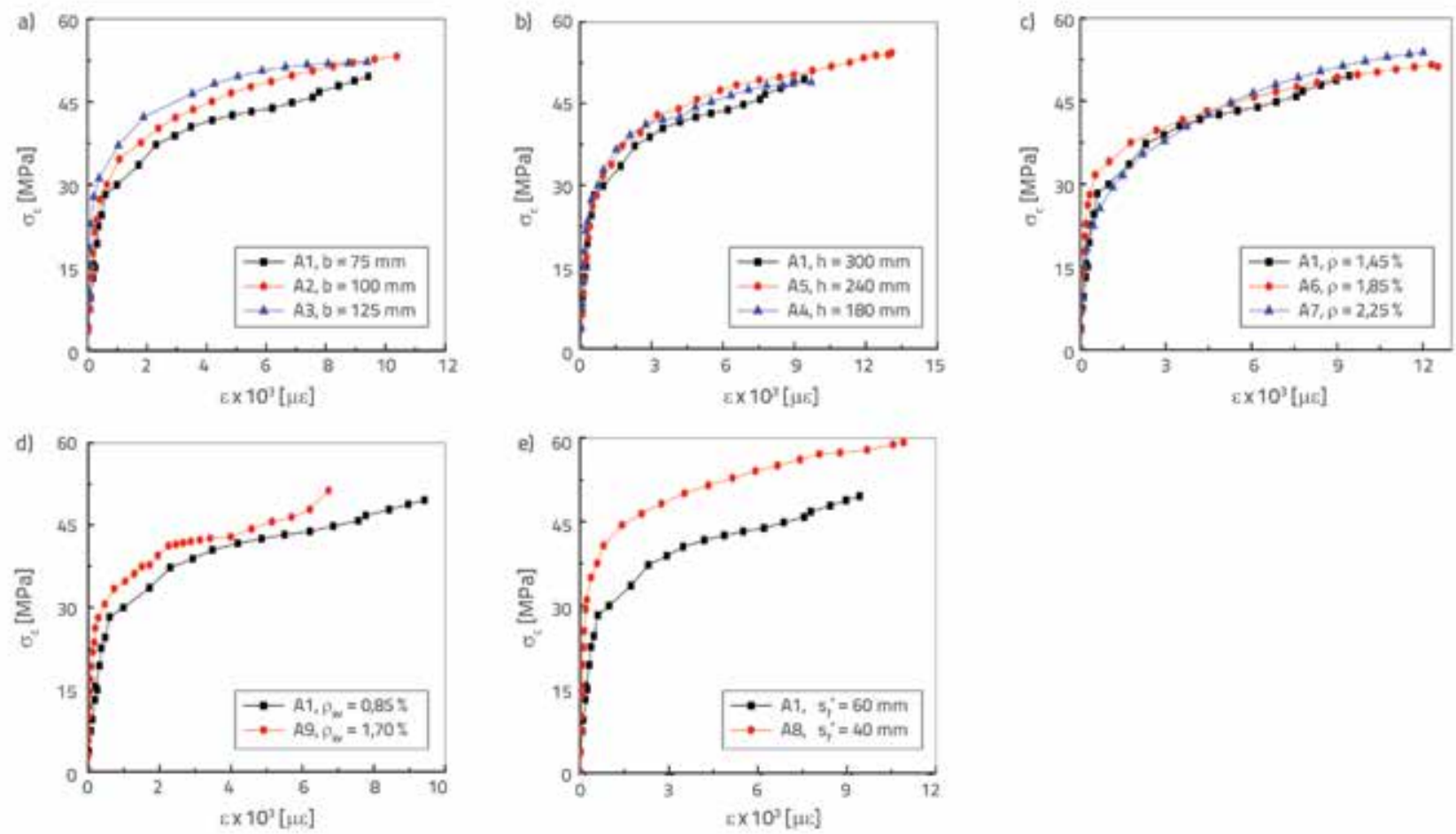

Figure 12. Effect of different parameters on circumferential strain of CFRP strips: a) Width; b) Height; c) Reinforcement ratio; d) Stirrup ratio; e) CFRP strip spacing

strain of the PVC tube decreased as the $s_{f}^{\prime}$ or $\rho_{s v}$ increased. In contrast, the influence of the $b, h, \rho$ on ultimate strain of the PVC tube was not significant. For instance, the ultimate strain of the PVC tube increased by $2.1 \%$ when the $\rho$ increased from $1.45 \%$ to $2.25 \%$. Compared to the PCR$B J$, the PRBJ did not show the strengthening stage, and the PVC tube buckled at earlier stage, as shown in Figure 11.e. Therefore, the PCRBJ showed better performance than the PRBJ.
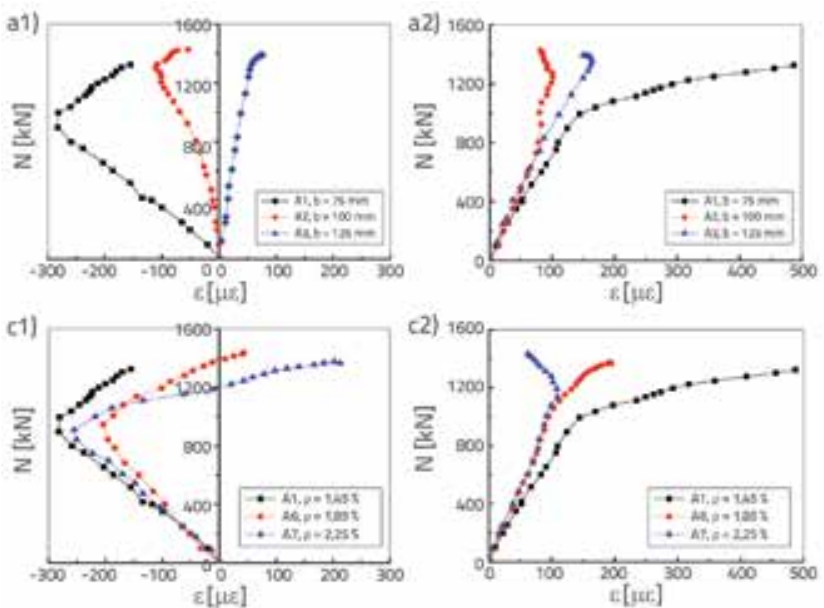

\subsubsection{Circumferential strain of CFRP strip}

The relationships between the $\sigma-\varepsilon$ of CFRP strips is depicted in Figure 12. The stress-strain curves included three stages: elastic stage, crack developing stage, and strengthening stage. In the elastic stage, the strain of the CFRP strips increased linearly with an increase in stress. With the further increase of load, the strain of CFRP strips deviated linearly, and the PCRBJ came to the stage of fracture development. Subsequently, the longitudinal rein-
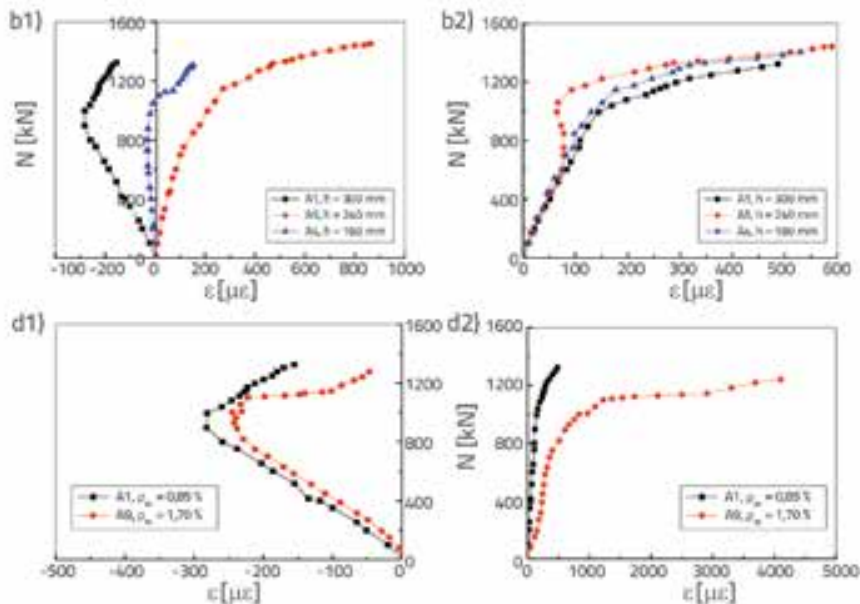

Figure 13. Longitudinal and transverse strains of concrete: a) effect of ring beam width on strain of concrete: longitudinal strain of concrete (a1) and transverse strain of concrete (a2); b) effect of the ring beam height on strain of concrete: longitudinal strain of the concrete (b1) and transverse strain of concrete (b2); c) effect of ring beam reinforcement ratio on strain of concrete: longitudinal strain of concrete (c1) and transverse strain of concrete (c2); d) effect of the coefficient of transverse reinforcement on strain of concrete: longitudinal strain of concrete (d1) and transverse strain of concrete (d2) 
forcement yielded. The PCRBJ entered the strengthening stage, and the strain of CFRP strips significantly increased. Finally, PCRBJ reached ultimate strength and the PVC tube cracked.

Obviously, the effects of all studied parameters on the strain of CFRP strips were similar to those of the PVC-CFRP tube, as shown in Figure 12. The increase in the $s_{\mathrm{f}}^{\prime}$ or $\rho_{\mathrm{sv}}$ decreased the ultimate strain of CFRP strips. The influence of the $b, h$, and $\rho$ on CFRP strips strain was not obvious.

\subsubsection{Strain of concrete in joint zone}

The influence of the $b, h, \rho$ and $\rho_{\mathrm{sv}}$, on longitudinal and transverse strain of concrete is depicted in Figure 13. Initially, the concrete strain in the joint zone increased linearly, and the PCRBJ was in the elastic stage. The concrete in the joint zone was always in a tension state in transverse direction. With an increase of $b$ and decrease of $h$ of the ring beam, the growth rate of the transverse and longitudinal strains of the concrete in joint zone decreased, and the longitudinal strain of the concrete in the joint zone gradually changed from compression to tension, as shown in Figure13.a and Figure13.b. This can be explained by the fact that the concrete around the joint zone received extrusion by the increased deformation of longitudinal concrete. The increase in $b$ increased the confinement effect of concrete in the joint zone, and decreased the transverse deformation of concrete in the joint zone. However, the increase in $h$ had adverse effect on the transverse and longitudinal strains of concrete in the joint zone.

The growth rate of transverse strain of concrete in the joint zone decreased with an increase of $\rho$, while the effect of $\rho$ on longitudinal strain was not obvious, as shown in Figure 13.c. This may come from the fact that an increase in $\rho$ increased the confining effect of concrete on the joint core, and decreased the transverse deformation of concrete in the joint zone, which effectively confined the development of vertical cracks in the side of the joint zone.

As the $\rho_{s v}$ increased, the growth rate of longitudinal strain of concrete in joint zone decreased, as shown in Figure 13.d. This was mainly because the confining effect of the concrete on the joint core increased, and longitudinal deformation of concrete in the joint zone decreased as the $\rho_{s v}$ increased, which significantly confined development of lateral cracks in the joint zone. The influence of the $\rho_{\mathrm{sv}}$ on transverse strain in the joint zone was not obvious.

\subsection{Load-displacement curve}

Figure 14 shows the relationship between load and displacement of specimens. Obviously, consistent with the above description, the load-displacement curves consist of three stages (i.e., the elastic stage, the crack developing stage and the strengthening stage). Initially, the load-displacement curves of the PCRBJs were approximately linear showing an elastic behaviour of specimen. As the load increased, the load-displacement curves started to deviate from linearity, and the specimens entered the crack developing stage. As the load increased further, the confinement effect of PVC-CFRP on specimens increased significantly, and specimens entered the strengthening stage. Finally, the specimens reached the ultimate strength and the PVC tube cracked. As shown in Figure 14, the displacement of specimens decreased as the $b, h$ or $s_{f}^{\prime}$ increased. This was mainly due to the fact that the confinement effect of ring beam on concrete core increased as the $b$ and $h$ increased. Additionally, the increase in
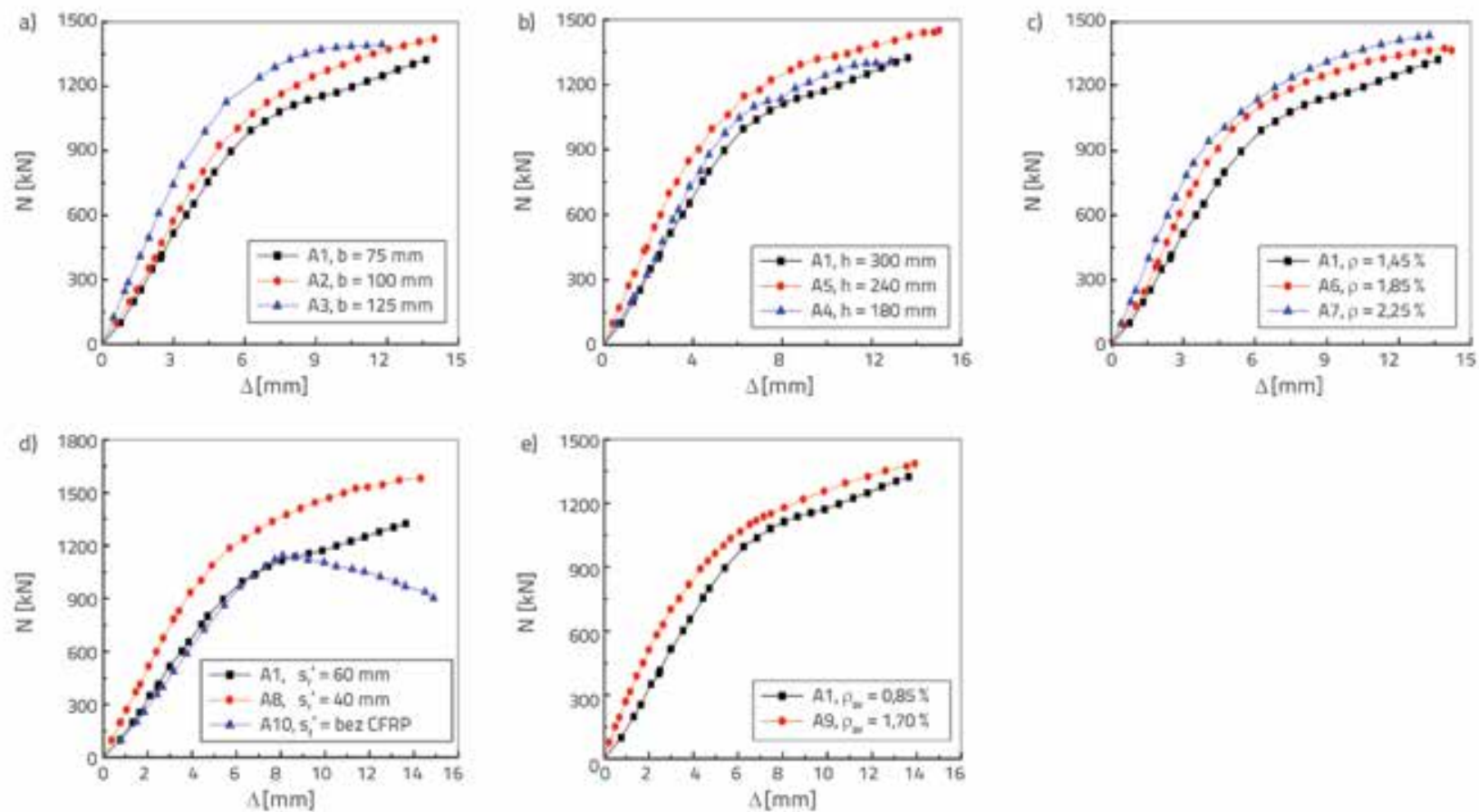

Figure 14. Load-displacement curves: a) width; b) height; c) proportion of longitudinal reinforcement; d) proportion of transverse reinforcement; e) CFRP strip clearance 
$s_{f}^{\prime}$ decreased the confinement effect of PVC tube on concrete core. The effect of $\rho$ and $\rho_{s v}$ on the displacement of specimens was not obvious. For example, the displacement of specimens at the same load decreased by $1.4 \%$ when the $h$ increased from $240 \mathrm{~mm}$ to $300 \mathrm{~mm}$.

\section{Numerical analysis of load-displacement relationship}

\subsection{Modelling of PFCC}

As recommended by Yu [12], the model for predicting the axial stress of PFCC is depicted in the following formulas, as shown in Figure 15.

$$
\begin{array}{ll}
\sigma_{c z}=0,58 E_{c} \varepsilon_{c z}-\frac{\left(E_{c}-E_{2}\right)^{2}}{12 f_{R o}} \varepsilon_{c z}^{2} & 0 \leq \varepsilon_{c z} \leq \varepsilon_{\mathrm{t}} \\
\sigma_{c z}=f_{R o}+E_{2} \varepsilon_{c z} & \varepsilon_{\mathrm{t}} \leq \varepsilon_{\mathrm{cz}} \leq \varepsilon_{\mathrm{ccR}}
\end{array}
$$

Where, $\sigma_{\mathrm{cz}}, \varepsilon_{\mathrm{cz}}$ are the axial stress and axial strain of PVC-CFRP confined concrete column, respectively; $E_{c}$ is the Young's modulus of concrete; $\mathrm{E}_{2}$ is the slope of the strengthened section; $f_{\mathrm{RO}}$ is the intercept of the straight line of PFCC; $\varepsilon_{t}$ is the intersection of the parabola and the enhanced section line; $\varepsilon_{\mathrm{ccR}}$ is the axial ultimate strain of PFCC.

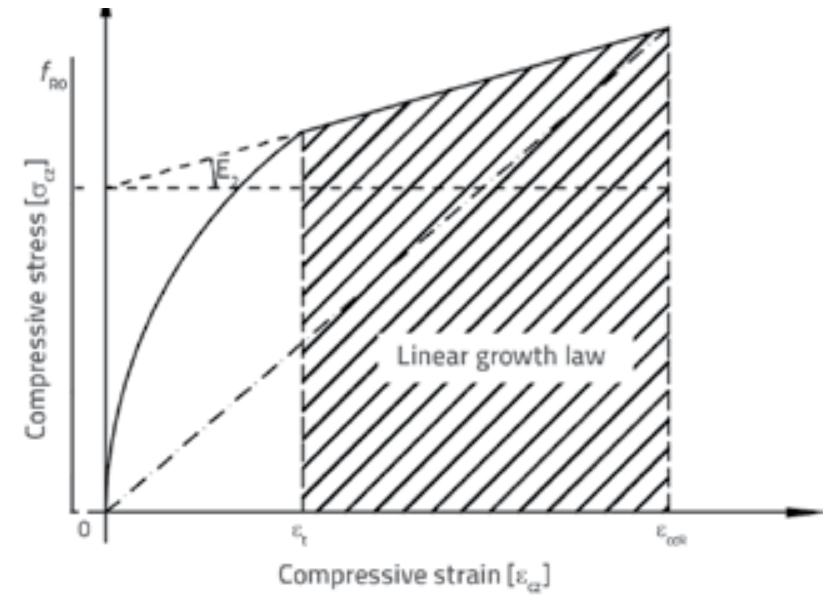

Figure 15. Stress-strain model of PFCC

\subsection{Modelling of the joint}

A modified model for predicting the stress-strain relationships of joint was developed on the basis of the Mander's model and Yu's model [26-27], as shown in Eq. (3), and Figure 16.

$\sigma_{c j}=\frac{f_{c c}^{\prime} x r}{r-1+x^{r}}$

$x=\frac{\varepsilon_{c j}}{\varepsilon_{c c}}$

$\varepsilon_{c c}=\varepsilon_{c o}\left[1+\eta\left(\frac{f_{c c}^{\prime}}{f_{c}}-1\right)\right]$

$$
\begin{aligned}
& f_{c c}^{\prime}=\beta_{h}\left(\beta_{c} \beta_{1} f_{c}+2 \alpha \lambda_{t, 1} \frac{d_{c o r, 1}}{d} f_{c, 0}+2 \alpha \lambda_{t, 2} \frac{d_{c o r, 2}}{d} f_{c, 1}\right) \\
& \eta=8.98043-2.24331(h / d)-0.18965(h / d)^{2} \\
& r=\frac{E_{c}}{E_{c}-E_{c e s}} \\
& E_{c e s}=\frac{f_{c c}^{\prime}}{\varepsilon_{c c}}
\end{aligned}
$$

Where, $\sigma_{\mathrm{cj}}$ and $\varepsilon_{\mathrm{cj}}$ are the axial stress and axial strain of the joint zone, respectively; $f_{c c}^{\prime}$ and $\varepsilon_{c c}$ are the axial peak stress and strain of the joint zone, in which $\varepsilon_{\text {co }}$ is the axial peak strain of unconfined concrete; $\eta$ is the corrected parameter of peak strain; $d$ is the internal diameter of PVC tube; $r$ is the parameter that controlls the shape of the stress-strain curve; $\beta_{\mathrm{h}}$ is the effect coefficient of height for the joint; $\beta_{c}$ is the effect coefficient of concrete; $\beta_{1}$ is the improvement factor for local compressive concrete; $\alpha$ is the reduction coefficient of indirect steel bar on concrete; $f_{c}$ stands for compressive strength of unconfined concrete; $f_{c, i}$ represents compressive strength of concrete after constraint by the $i^{\text {th }}$ annular reinforcement; $\lambda_{\mathrm{t}, \mathrm{i}}$ is the characteristic value of stirrups.

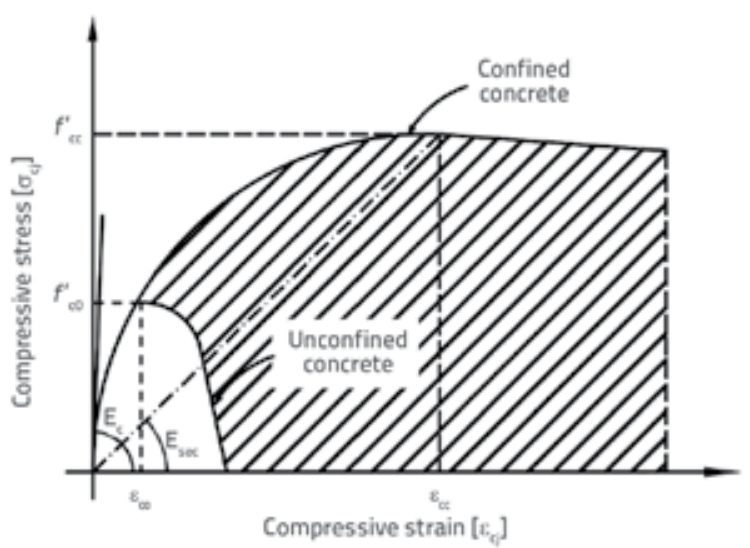

Figure 16. Stress-strain model of the joint

\subsection{Numerical analysis}

\subsubsection{Assumptions}

In order to simplify the calculation, several assumptions were made in this study:

- The specimen is in an ideal axial compression state without any eccentricity

- The ultimate strength of PFCC is equal to that of the joint zone

- The axial displacement of the specimen is the superposition of the displacement of PFCC and displacement of joint zone

- The stress-strain relations of PFCC and joint zone given in Eqs. (1-2) and (3-9) are adopted. 


\subsubsection{Equilibrium equation}

According to equilibrium equation and geometrical conditions, the following formulas can be established in this study.

$N=N_{z}=N_{j}$

where

$N_{z}=\sigma_{c z} A_{c}$

$N_{j}=\sigma_{\mathrm{cj}} A_{c}$

$\Delta=\Delta_{z}+\Delta_{j}$

whereby $\Delta_{z}$ and $\Delta_{j}$ are given Eq. (14) and (15):

$\Delta_{z}=\varepsilon_{\mathrm{cz}} I$

$\Delta_{j}=\varepsilon_{\mathrm{cj}} h$

where, $\mathrm{N}$ is the of specimen, $\mathrm{N}_{z}$ represents the ultimate strength of PFCC, and $N_{\mathrm{i}}$ denotes the of the joint. $\Delta$ is the axial displacement of the specimen, $\Delta_{z}$ stands for the axial displacement of PFCC, $\Delta$ represents the axial displacement of the joint. / is the length of the column, $h$ is the height of the ring beam, $A_{c}$ is the segmental area of concrete in PVC tube.

\subsubsection{Calculation process}

In order to estimate the load-displacement curve of the PCRBJ, the numerical analysis approach was proposed using MATLAB. The following calculation steps were adopted:

1. input the initial equivalent strain value $\varepsilon_{\mathrm{c}, \mathrm{i}}\left(\varepsilon_{\mathrm{c}, \mathrm{i}}=0,01\right)$ of the joint zone and the estimated of the specimen, $N_{e^{\prime}}$ which is given in reference [28];

2. Determine the equivalent axial stress value $\sigma_{\mathrm{cj}, \mathrm{i}}$ according to Eq. (3) and Eq.(4);

3. Determine the value of $N_{j, i}$ according to Eq. (12);

4. Eestimate the of specimen $N_{i}=N_{j, r}$ and calculate the value of $\sigma_{\mathrm{czi}}$ based on Eq. (10) and Eq. (11);

5. Estimate the value of $\varepsilon_{c z, i}$ according to Eq. (1) and Eq. (2);

6. Predict the value of $\Delta_{2 \mathrm{i}}$ and $\Delta_{\mathrm{i}}$ based on Eq. (14) and Eq. (15) ;

7. Calculate the displacement of the specimen $\Delta_{i}$ using Eq. (13).

If the equilibrium condition $N_{e}-N_{i} \geq 0,1$, is satisfied, output the load $N_{i}$ and displacement $\Delta_{i}$, then repeat the steps (2-7); otherwise terminate the computation.

8. Ooutput the load-displacement curves of the specimens. More details can be found in the flow chart shown in Figure 17.

The load-displacement curves of specimens predicted by the numerical analysis approach and the measured experimental results are plotted and compared in Figure 18. The results show that the estimated values agree well with test results, which demonstrates that the numerical analysis approach is highly accurate.

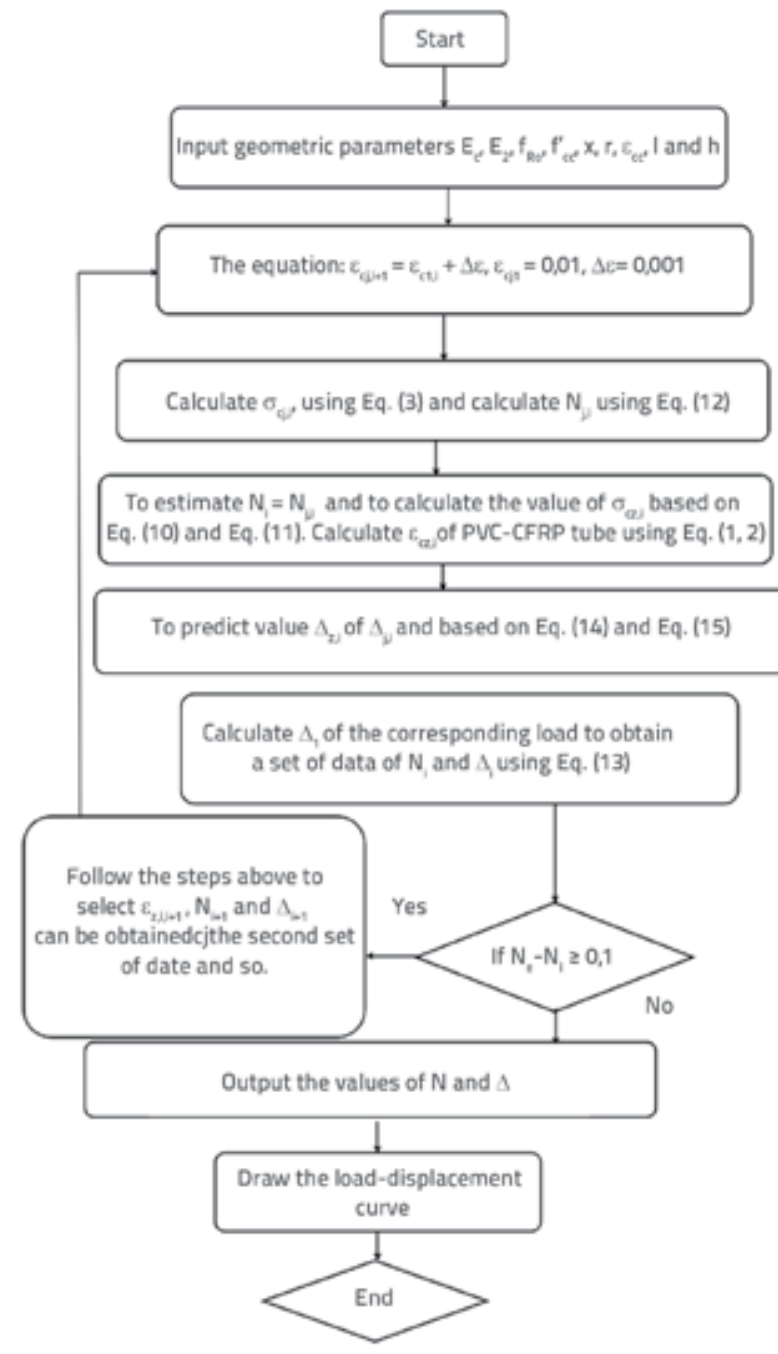

Figure 17. Flow chart for prediction of load-displacement curves

\subsubsection{Parametric studies}

Parametric studies using the proposed numerical analysis approach were carried out to investigate the influences of different parameters on specimen behaviour, including the concrete strength grade of specimen, height of the column $(H)$, width, height, the reinforcement ratio of ring beam, and CFRP strip spacing. Specimen A1 was employed as comparative reference. The load-displacement curves of the specimens with different parameters are shown in Figure 19. Compared to experimental results, the effects of $b, h, \rho$, and CFRP strip spacing of PCRBJ estimated by the parametric studies were similar, which further demonstrates accuracy of the numerical analysis approach. Figure 19 (a) illustrates the effects of the concrete strength grade of specimen, where the specimen with a higher concrete strength grade had a higher ultimate strength. This is mainly due to the fact that the compressive strength of the PCRBJ is mostly provided by concrete. Apparently, the increase in the height of column decreases the ultimate strength of specimen, as shown in Figure 19.b. 

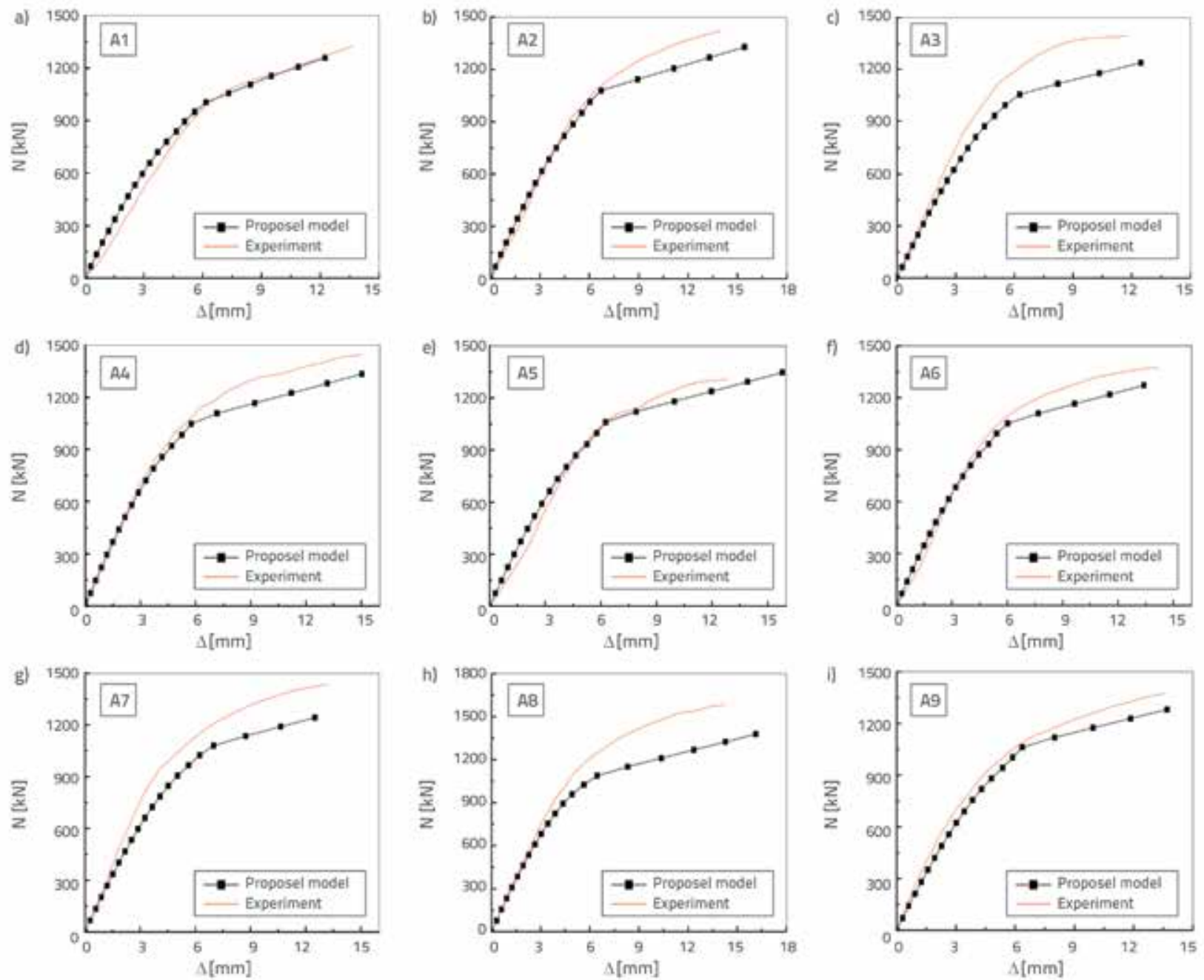

Figure 18. Comparison of load-displacement curves estimated by numerical method and test data
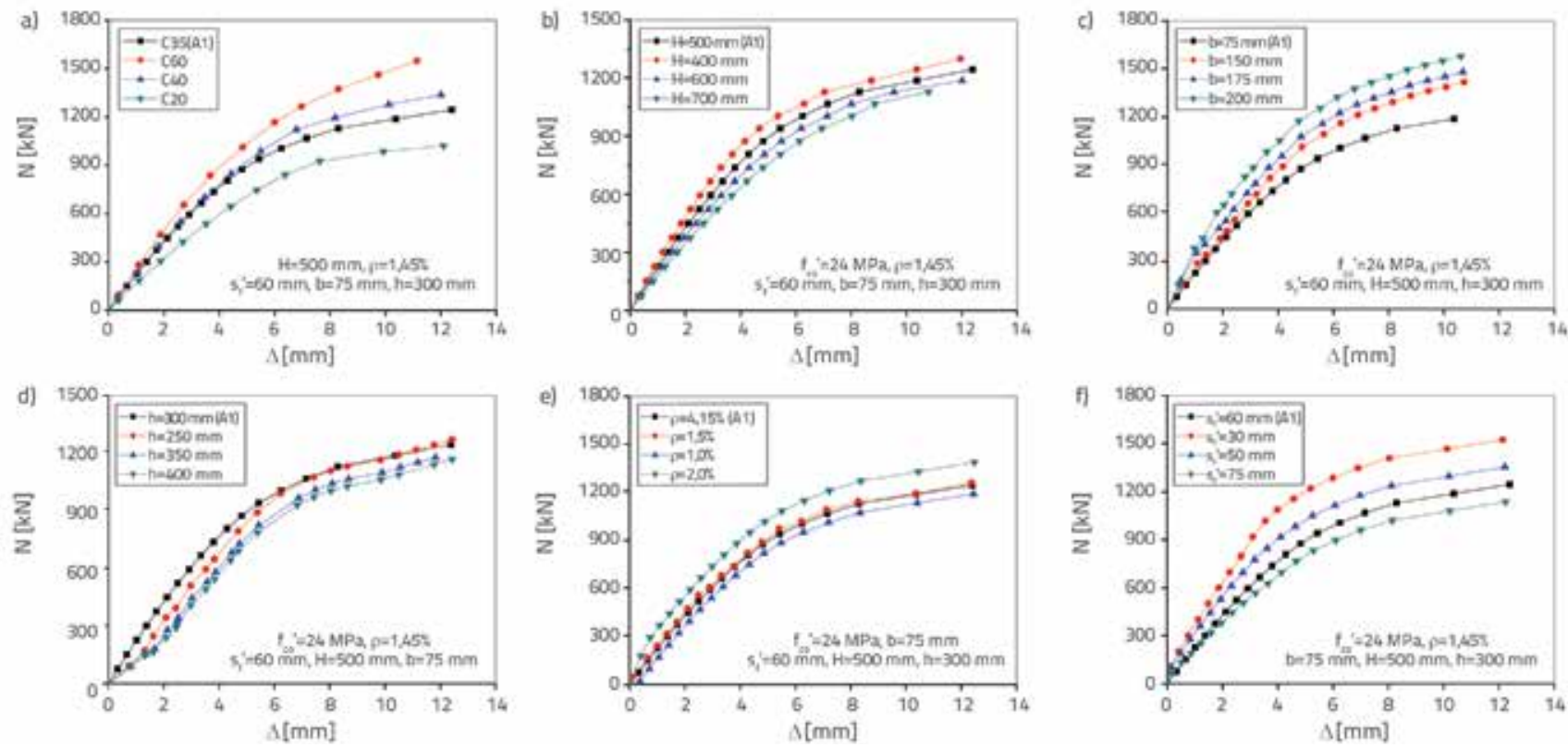

Figure 19. Parametric studies of load-displacement curves: a) Impact of sample concrete class; b) Impact of pillar height; c) Width impact; d) Influence of height; e) Impact of reinforcement coefficient; f) Impact of CFRP strip spacing 


\section{Conclusion}

In this study, axial compression experiments were carried out for one PRBJ and nine PCRBJ, and numerical analysis was conducted in order to predict load-displacement curves of specimens. The following main conclusions were reached:

- PRBJ is distinguished by the PVC tube buckling, and the PCRBJ is characterized by PVC tube cracking and CFRP strips fracture.

- The ultimate strength of PCRBJ decreases with an increase in CFRP strip spacing. The height, width, stirrups ratio and reinforcement ratio, have a little effect on ultimate strength of specimens.

- The circumferential strain of CFRP strip, and axial strain of PVC tube, gradually increase with an increase in CFRP strip spacing. Other studied parameters have a small effect on the CFRP strip circumferential strain and PVC tube axial strain.

- The development rate of transverse and longitudinal strains of concrete in the joint zone decreases with an increase in width and decrease in height. The development rate of the transverse strain of concrete in joint zone decreases with an increase in reinforcement ratio. The development rate of longitudinal strain of concrete in joint zone decreases with an increase in stirrup ratio.

- The numerical analysis approach for predicting the loaddisplacement relationship of PCRBJ is proposed based on Mander's and Yu's models. The numerical method results are in good agreement with test data. Additionally, further parametric studies are to be carried out using this approach to numerical analysis.

\section{Acknowledgments}

The research is funded by National Natural Science Foundation of China (No. 51578001, 51608003, 51878002, and 51008001), Key Research and Development Plan of Anhui Province (No. 1704a0802131), and Outstanding Young Talent Support Program of Anhui Province (No. gxyqZD2016072).

\section{REFERENCES}

[1] Jarc Simonič, M., Gostič, S., Bosiljkov, V., Žarnić, R.: Testing and analysis of walls strengthened with FRP, GRAĐEVINAR, 66 (2014) 6, pp. 533-548, https://doi.org/10.14256/JCE.960.2013

[2] Dhahir, M.K.: Shear strength of FRP reinforced deep beams without web reinforcement, Composite Structures, 16 (2017), pp. 223-232. http://211.70.148.4:8000/rwt/EN_ELSEVIER/https/ MSYXTLUQPJUB/10.1016/j.compstruct.2017.01.039

[3] Zomorodian, M., Yang, G., Belarbi, A., et al.: Behaviour of FRP-strengthened RC elements subjected to pure shear. Construction \& Building Materials, 170 (2018), pp. 378391, http://211.70.148.4:8000/rwt/EN_ELSEVIER/https/ MSYXTLUQPJUB/10.1016/j.conbuildmat.2018.03.004

[4] Corradi, M., Speranzini E., Borri, A., et al.: In-plane shear reinforcement of wood beam floors with FRP, Composites Part B, 37 (2006) 4-5, pp. 310-319, http://211.70.148.4:8000/ rwt/EN_ELSEVIER/https/MSYXTLUQPJUB/10.1016/j. compositesb.2005.11.003

[5] Castillo, E.D.R., Griffith, M., Ingham, J.: Seismic behaviour of RC columns flexurally strengthened with FRP sheets and FRP anchors, Composite Structures, 203 (2018), pp. 382395, http://211.70.148.4:8000/rwt/EN_ELSEVIER/https/ MSYXTLUQPJUB/10.1016/j.compstruct.2018.07.029

[6] Roy, B., Laskar, A.l.: Cyclic Performance of Beam-Column Subassemblies with Construction Joint in Column Retrofitted with GFRP, Structures, 14 (2018), pp. 290300, http://211.70.148.4:8000/rwt/EN_ELSEVIER/https/ MSYXTLUQPJUB/10.1016/j.istruc.2018.04.002

[7] Sevil Yaman, T.: Behaviour of precast concrete beams prestressed with CFRP strands, GRAĐEVINAR, 68 (2016) 10, pp. 775-786, https://doi.org/10.14256/JCE.1624.2016
[8] Ali, O., Bigaud, D., Riahi, H.: Seismic performance of reinforced concrete frame structures strengthened with FRP laminates using a reliability-based advanced approach, Composites Part B, 139 (2018), pp. 238-248, http://211.70.148.4:8000/ rwt/EN_ELSEVIER/https/MSYXTLUQPJUB/10.1016/j. compositesb.2017.11.051

[9] Feng, P., Cheng, S., Bai Y., et al.: Mechanical behaviour of concretefilled square steel tube with FRP-confined concrete core subjected to axial compression, Composite Structures, 123 (2015), pp. 312-324, http://211.70.148.4:8000/rwt/EN_ELSEVIER/https/ MSYXTLUQPJUB/10.1016/j.compstruct.2014.12.053

[10] Le, T.D., Pham, T.M., Hao, H., et al.: Flexural behaviour of precast segmental concrete beams internally prestressed with unbonded CFRP tendons under four-point loading, Engineering Structures, 168 (2018), pp. 371-383, http://211.70.148.4:8000/ rwt/EN_ELSEVIER/https/MSYXTLUQPJUB/10.1016/j. engstruct.2018.04.068

[11] Mirmiran, A., Shahawy, M.: Behaviour of concrete columns confined by fibre composites, Journal of Structural Engineering, 123 (1997), pp. 583-590

[12] Saafi, M.: Development and behaviour of a new hybrid column in infrastructure systems [D]. Huntsville, Texas: Doctoral Dissertation of the University of Alabama. 2001.

[13] Yu, F.: Experimental study on reinforced concrete axial compression short columns of PVC-FRP tube, Journal of Building Structure, 34 (2013), pp. 129-136. (in Chinese)

[14] Yu, F.: Experimental study and theoretical analysis of mechanical properties of PVC-FRP confined concrete columns[D]. XiAn: Xi'an University of Architecture and Technology. 2007. 
[15] Jiang, S.F., Ma, S.L., Wu, Z.Q.: Experimental study and theoretical analysis on slender concrete-filled CFRP-PVC tubular columns, Construction \& Building Materials, 53 (2014), pp. 475487, http://211.70.148.4:8000/rwt/EN_ELSEVIER/https/ MSYXTLUQPJUB/10.1016/j.conbuildmat.2013.11.089

[16] Ma, S.L., Jiang, S.F.: Experimental study on bearing capacity of CFRP-PVC tube concrete axial compression column, Journal of Civil Engineering, 47 (2014), pp. 99-106. (in Chinese)

[17] Fakharifar, M., Chen, G.: Compressive behaviour of FRP-confined concrete-filled PVC tubular columns, Composite Structures, 141 (2016), pp.91-109, http://211.70.148.4:8000/rwt/EN_ELSEVIER/ https/MSYXTLUQPJUB/10.1016/j.compstruct.2016.01.004

[18] Fakharifar, M., Chen, G.: FRP-confined concrete filled PVC tubes: A new design concept for ductile column construction in seismic regions, Construction \& Building Materials, 130 (2017), pp. 1-10, http://211.70.148.4:8000/rwt/EN_ELSEVIER/https/ MSYXTLUQPJUB/10.1016/j.conbuildmat.2016.11.056

[19] Jiang, S.F., Wu, Z.L., Wu, Z.Q.: Experimental study on hysteretic behaviour of circular section reinforced concrete composite columns with FRP-PVC pipe, Journal of Building Structure, 35 (2014), pp. 111-118. (in Chinese)

[20] Yu, F., Xu, G.S., Cheng, A.C.: Analysis of shear capacity of reinforced concrete columns with PVC-CFRP tube under low cycle repeated loading, Journal of Building Structure, 37 (2016), pp. 106 -112. (in Chinese)

[21] Yu, F., Xu, G.S., Niu, D.T., Cheng, A.C., Wu, P., Kong, Z.Y.: Experimental study on PVC-CFRP confined concrete columns under low cyclic loading, Construction \& Building Materials, 177 (2018), pp. 287- 302, http://211.70.148.4:8000/rwt/EN_ELSEVIER/https/ MSYXTLUQPJUB/10.1016/j.conbuildmat.2018.05.111
[22] GB/T 228.1 - 2010, Metallic materials - Tensile testing - Part 1: Method of test at room temperature.: Standards Press of China, Beijing, China, 2010.

[23] GB/T 8804.1 - 2003, Thermoplastic pipes - Determination of tensile properties.: Standards Press of China, Beijing, China, 2003.

[24] GB/T 3354 - 2014, Test method for tensile properties of orientational fibre reinforced polymer matrix materials.: Architecture \& Building Press, Beijing, China, 2014.

[25] GB/T 50081- 2002, Standard for test method of mechanical properties on ordinary concrete: Architecture \& Building Press, Beijing, China, 2002.

[26] Mander, J.B., Priestley, M.J.N., Park, R.: Theoretical stress-strain model for confined concrete, Journal of Structural Engineering ASCE, 114 (1988), pp. $1804-1826$.

[27] Yu, F., Zhang, N.N., Niu, D.T., Kong, Z.Y., Zhu, D.F., Wang, S.L., Fang, Y.: Strain analysis of PVC-CFRP confined concrete column with ring beam joint under axial compression Composite Structures, 224 (2019), 111012, https://doi.org/10.1016/j. compstruct.2019.111012

[28] Yu, F., Li, D.A., Niu, D.T., Zhu, D.F., Zhang, N.N., Kong, Z.Y., Fang, Y.: A model for ultimate bearing capacity of PVC-CFRP confined concrete column with reinforced concrete beam joint under axial compression, Construction \& Building Materials, 214 (2019), pp. 668-676, https://doi.org/10.1016/j.conbuildmat.2019.04.131 